\title{
ISSUES IN THE IMPLEMENTATION OF Katarungang Pambarangay - Philippine LOCAL JUSTICE SYSTEM: INPUT TOWARDS THE DEVELOPMENT OF E-PABARANGAY
}

\author{
Joanna E. De Torres and Marco Jr. N. Del Rosario
}

College of Computer Studies, Laguna State Polytechnic University, Laguna, Philippines

\begin{abstract}
An ICT-enabled government provides citizens with improved access to information and services anytime and anywhere. Currently, eighty barangays in the city of San Pablo, Philippines have the means to implement ICT-enabled projects since they are all provided with ICT equipment. However, several barangay transactions are still done manually such as filing and processing complaints at Katarungang Pambarangay, a community-based mechanism for dispute resolution. This study aims to determine the problems encountered in Katarungang Pambarangay, to determine the level of readiness of the barangay in utilizing an information system and to propose a software application as a solution to the problems. The proponents conducted qualitative and quantitative methods. An interview was conducted with a DILG representative to identify the problems. While a survey questionnaire was given to the barangay to determine their readiness in utilizing an e-system. This research analyses the findings and presents recommendations.
\end{abstract}

\section{KEYWORDS}

Government, e-Government, Information Technology, Information System, Philippines, Justice System, Katarungang Pambarangay

\section{INTRODUCTION}

Barangays serves as the primary planning and implementing unit of government in the Philippines. As the basic political unit, it implements the policies, plans, programs, projects, and activities in the community [1]. It participates in the implementation of several national programs and projects such as the country's e-government plan. Philippines implements its e-government master plan (EGMP) which is a blueprint in integrating ICT for the whole government. This plan helps the Philippines to attain its vision to provides responsive and transparent citizen-centered services online by creating a digitally empowered and integrated government for a globally competitive Filipino nation [2]. The use of information and communications technology (ICT) and other web-based technologies to improve information access as well as the delivery, efficiency, and effectiveness of service to the public is what defined e-governance. A government that supports and utilizes ICT to their services was able to provide easy access to information to their citizens anytime anywhere. It also allows the government to show transparency and accountability in its operations [3]. To fully embody its vision, the country's e-Government Management Group implements, facilitates and evaluates the standards, policies, and plans for DOI: 10.5121/ijmpict.2019.10402 
International Journal of Managing Public Sector Information and Communication Technologies (IJMPICT)

Vol. 10, No.1/2/3/4, December 2019

ICT. The group also implements and monitors several plans such as the National e-Government Plan and Information Systems Strategic Plans. Furthermore, they provide ICT services to government agencies and develops and implements the ICT human capital and professionalization program for government. In response, few agencies were transitioning from manual procedures to the utilization of an information system which is helping them in the attainment of the vision.

Katarungang Pambarangay (KP) is the Philippines' mechanism of resolving disputes within a community. Disputes between members of the same community, whether by municipal or city level, is covered by KP. This mechanism involves the Barangay Chairman and other members of the communities (the Lupon members) as intermediaries. They act as mediators, conciliators, and occasionally arbitrators. The Philippines justice system was first established by the presidential decree 1508 in 1978 and Batas Pambansa Blg. 337. However, it was improved by the Republic Act No. 7160 or also called the Local Government Code of 1991. This includes the policies and procedures that the local government unit should follow and implement. This justice system aimed to speed up the administration of justice, reduce the number of imperceptive filing of cases and to unclog court dockets. These objectives result in an improved quality of justice allotted by the courts to sustain and appreciate the tradition of agreeably settling disagreements in a community [4].

Currently, there are eighty (80) barangays in the city of San Pablo that have all the means to implement ICT enabled projects. Since the Philippine government is aiming to revolutionize its services, they are all given and provided with several ICT equipment and internet technologies. However, despite the support of the government and availability of resources, there are several official barangay transactions still being done manually. One of these manually performed transaction is the implementation of the Katarungang Pambarangay or Barangay Justice System.

\subsection{Objectives}

The main objective of this study is to address the issues experienced by Katarungang Pambarangay in the city of San Pablo to improve the quality of public service.

Specifically, the study aims to:

1. Determine the availability of ICT equipment that supports the implementation of Philippine E-Government initiatives in the different barangay.

2. Determine the level of readiness of the barangay secretaries in utilizing information systems to be used in their respective barangays.

3. Determine the problems/issues encountered in the manual implementation of the barangay justice system.

4. Provide a solution by designing a web-based system to the addressed issues using ICTenabled computer program or application; 
International Journal of Managing Public Sector Information and Communication Technologies (IJMPICT) Vol. 10, No.1/2/3/4, December 2019

\section{RELATED LITERATURE}

\subsection{Philippine Government Composition}

As mandated by law, the Philippine government created an agency that assists the president in exercising supervision over local governments called the Department of the Interior and Local Government (DILG) [1]. It was created in pursue to ensure public safety, promote peace and order, and further strengthen the local government capability aimed towards the delivery of basic service to the citizenry. To successfully implement its programs and policies throughout the country it establishes several regional offices. Moreover, it extends its services by working with different agencies such as other national government agencies (NGAs), and civil society, including non-government agencies (NGOs) and people's organizations (POs) and especially with the local government units (LGUs) [5].

LGUs supervises the conveyance of basic services and facilities to the citizens since it is the nearest component of the government to its citizens. It can be classified into four groups, each having the right and power to regulate political, economic, social, and administrative affairs [6]. The four groups are the autonomous regions (the Autonomous Region in Muslim Mindanao is the only autonomous region in the country), the cities and provinces, the municipalities and the barangays (villages). As the smallest political unit in the country, every municipality and city is made up of barangays [7]. It is governed by an elected leader called Punong Barangay (Chief Executive), the Sangguniang Kagawad (Barangay Members), and the Sangguniang Kabataan (Youth) Chairman. There are 42,044 barangays in the Philippines as of May 2019. The role of the barangay is to support the government by implementing its programs and policies be it in a form of implementing the law or by supporting the government initiative in integrating ICT in its processes [8].

\subsection{Philippine E-Government}

E-government uses ICT to interactively communicate and to give quality services to its community, whether in the public or private sector [9]. The utilization of different electronic media in facilitating the processes and services in the government defines e-government [10]. It intends to make the government public services improve through the implementation of various Information and Communications Technologies (ICTs) to its most important clients which are the citizens. Technologies used in e-governance can be classified by where it is applied. One of these classifications is the internal ICT applications which refer to the solutions developed by streamlining in-house processes. Data encoding, document processing, document retrieval, and other administrative task accomplished by a government agency is an example of these processes. the Philippine government envisions that all the processes and services existing in the government agencies utilize ICT. The Philippine government designed and implement the EGovernment Master Plan (EGMP) which is a blueprint to make the entire government integrated with ICTs [2]. This plan allows the country to implement, facilitate and evaluate several government programs. One example of these programs is the eLGU which is the Electronic Governance in Local Government Unit. This program plans to change the Philippine local governance by transforming the local government into an electronically enabled unit. eLGU improves the delivery of public service, promotes transparency in the transactions with the government agencies and increases public access to government information and services. This program is composed of several projects such as the Electronic Treasury Operations Management 
International Journal of Managing Public Sector Information and Communication Technologies (IJMPICT) Vol. 10, No.1/2/3/4, December 2019

System (eTOMS), Electronic Business Permit and Licensing System (eBPLS), and Electronic Real Property Tax System (eRPTS), [3].

\subsection{Katarungang Pambarangay}

Katarungang Pambarangay is the system established to resolve disputes in the barangays in the Philippines [11],[12]. KP helps in avoiding the increase of criminality, one of the areas needed to be addressed in the Peace and Development Zones, by preventing peace and order in the community [4]. It provides all avenues to an amicable settlement to promote a fast administration of justice which results in the reduction of court cases. KP was able to settle several types of cases, criminal and civil, since its establishment [11]. This system was intended to give honor and recognition to Philippine's tradition and culture of settling disputes peacefully among family and barangay members. Instead of taking the conflicts at the court of justice, the tradition allows the Filipinos to settle such conflicts within the barangay. By honoring the tradition and making it into law, the court benefits in this since it contributes to minimizing the number of cases being filed which may lead to the congestion in court dockets. It was evident that KP was able to help in lessening the cases reported to the regular trial court especially those of civil cases [12]. Moreover, prolonged court litigation which produces animosity is being avoided by compelling both parties to resolve the issues through the intervention of the barangay. Beyond the intention of lessening the number of cases recorded in the court, higher societal goals, for an instance, decent citizenship and a solid community, can be attained [11]. However, the procedures/practices conducted in KP are not particularly being documented, meaning the records of the case proceedings and resolution are not available [12].

\section{Methodology}

A literature review was initially conducted in this study to comprehend different aspects of the issue and their importance to the Philippines' Katarungang Pambarangay. After the review of related literature and initial analysis of the phenomenon of interest, the proponents conducted a qualitative assessment. This was conducted in collaboration with a representative from the office of DILG through a consultative meeting. This aims to identify the issues encountered by the barangay officials in fulfilling their duties concerning the Katarungang Pambarangay. A set of questions were asked to the DILG representative. The research question asked were compiled into the following questions: (1) what are the processes that need the support of computer technology, and (2) what are the issues and problems encountered in implementing Katarungang Pambarangay. Data gathering took less than a day since the data needed by the proponents were readily available at the office of DILG in the city of San Pablo, Laguna. Moreover, to determine the level of readiness of the barangays in utilizing an information system, a survey was conducted. The respondents of the survey are the staff from different barangay. The following research questions were compiled: (1) Can they follow the instructions to run a software application, (2) do they understand file management, and (3) do they have the knowledge of basic computer concepts. These three research questions were assessed by making use of the data collected through a survey. Descriptive analysis was used to evaluate the gathered data.

Using the analyzed data as a basis, the proponents came up with a system design on how the intended solution will work. Use Case Diagram was used to show the actors that may be involved in the process and actions to be performed in utilizing the system. A database architecture was also designed by the proponents. 


\section{RESUlts AND DiscuSSION}

The interview questions consisted of two sections, one drawing information on the issues encountered in Katarungang Pambarangay and another is for determining the readiness of the barangay to utilize an information system. The succeeding sections present the results of the interview question for the representation of DILG during the consultative meeting and the results of the survey questionnaires answered by the barangay secretaries and official.

\subsection{Processes that needs support of Computer Technology}

The interview was conducted with the participation of the City Local Government Operations Officer (CLGOO) of the city of San Pablo, Laguna, Philippines. Based on the interview conducted, for the first section of the interview, the respondent enumerated the processes that needed the support of computer technology such as:

1. Filing of complaints;

2. Printing of forms;

3. Storage of important files; and

4. Notification for important dates.

The enumerated issues mentioned above are the processes that the CLGOO consider requiring an implementation for an information system. These issues resulted in the poor management of Katarungang Pambarangay. Moreover, these processes are the causes that the KP is commonly having problems with. Such problems and issues are presented in the following section.

\subsection{Issues Encountered in Katarungang Pambarangay}

The respondent, CLGOO of the City of San Pablo, answered the second part by enumerating the problems and issues encountered in handling the complaints. The following are the derived results:

1. Redundant encoding of substantial information in all Katarungang Pambarangay forms;

2. Voluminous paper works;

3. Lack of database files for all the complaints;

4. No effective control number system;

5. Some records were not properly monitored;

6. Some records were misplaced; and

7. Generating quarterly reports was not immediately attended due to other duties.

\subsection{Readiness of the Barangays to utilize an Information System}

\subsubsection{Readiness of ICT equipment and internet connection in all barangays in San Pablo City}

To sustain the usefulness of e-services, it is imperative to determine the readiness of the infrastructure of the in-house and online systems of the government [9]. The data provided by the office of DILG implies that all the 80 barangays in the city of San Pablo are equipped with 
essential ICT facilities. Having said that, it can easily be concluded that $100 \%$ of the barangay has the necessary equipment to support the utilization of an information system. Such equipment consists of, but not limited to, desktop computers, printers, and scanners. However, it is not clear if all these barangays have internet connectivity. A survey was conducted to determine the availability of internet connectivity in all the barangays in San Pablo City.

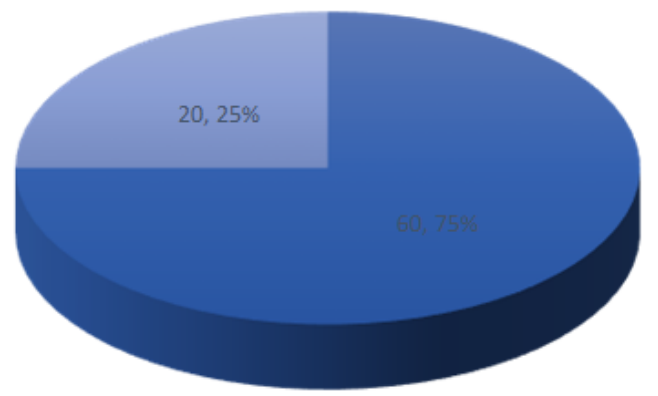

Figure 1. Availability of ICT Equipment and Internet Connection representation

Legend: A - Complete ICT Equipment with stable Internet Connection

B - Complete ICT Equipment without stable Internet Connection

As shown in Figure 1, sixty (60) barangays, which is $75 \%$ of the total barangay, are currently fully equipped with ICT facilities with a stable internet connection. On the other hand, it shows that $25 \%$ of the barangay are still unfortunate to experience a lack of internet connectivity. There are twenty (20) barangays that do not have a stable internet connection. However, in an interview with some of the respondents, such an issue was addressed by the barangay by purchasing and relying upon the internet connectivity using portable broadband devices owned personally by the barangay secretaries.

\subsubsection{Readiness of the staff to utilize an information system}

To determine the level of readiness of the barangay secretaries in utilizing an information system to be used in their respective barangays, a survey was conducted. The respondents were asked to measure their level of understanding and the knowledge they possessed in the questions mentioned earlier. A total of sixty-four (64) individuals responded to the survey comprising the barangay secretaries and barangay officials. Summary of the responses was presented below:

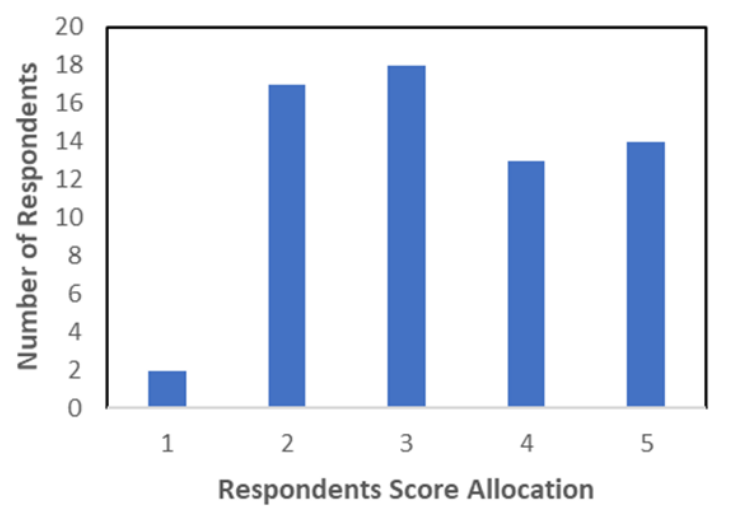


International Journal of Managing Public Sector Information and Communication Technologies (IJMPICT) Vol. 10, No.1/2/3/4, December 2019

Figure 2. Question Number 1 representation

$$
\text { Legend: Very High }=5 \text {, High }=4 \text {, Moderate }=3 \text {, Poor }=2 \text {, Very Poor }=1
$$

Table 1. Survey response scores.

\begin{tabular}{|c|c|}
\hline Response Score & Number of Responses \\
\hline 5 & 14 \\
\hline 4 & 13 \\
\hline 3 & 18 \\
\hline 2 & 17 \\
\hline 1 & 2 \\
\hline
\end{tabular}

Based on the result presented in Figure 2 and Table 1, most of the respondents can follow the instructions to run software applications at a moderate level. The moderate level respondents cover $28.13 \%$ of the total number of respondents. While $21.88 \%$ and $20.31 \%$ of the respondents confidently share that their level of knowledge in following instructions is "Very High" and "High", respectively. But, the result shows that $26.56 \%$ and $3.13 \%$ of the respondents have answered "Poor" and "Very Poor", respectively, which means that these respondents are having trouble following instructions in running a software application.

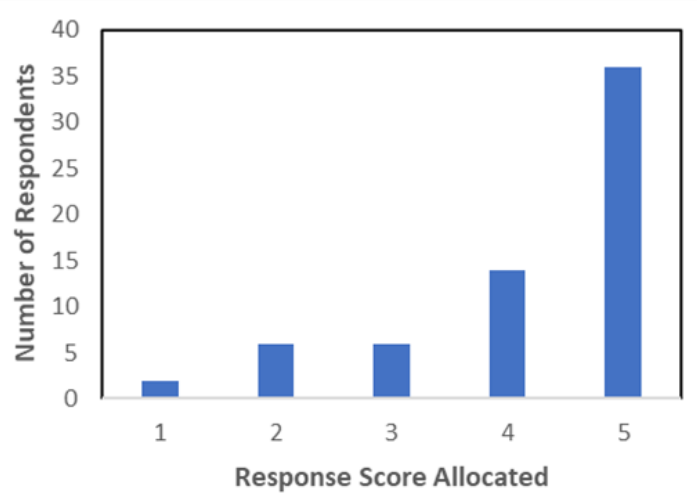

Figure 3. Question Number 2 representation

Legend: Very High $=5$, High $=4$, Moderate $=3$, Poor $=2$, Very Poor $=1$

Table 2. Survey response scores.

\begin{tabular}{|c|c|}
\hline Response Score & Number of Responses \\
\hline 5 & 13 \\
\hline 4 & 14 \\
\hline 3 & 17 \\
\hline 2 & 18 \\
\hline 1 & 2 \\
\hline
\end{tabular}

Figure 3 and Table 2 presents the result in the survey question about the respondents' level of understanding of File Management. With regards to the barangay officials and secretaries' 
International Journal of Managing Public Sector Information and Communication Technologies (IJMPICT)

Vol. 10, No.1/2/3/4, December 2019

knowledge in creating folders and directories, and recognizing several file types and extension, the respondents who answered that they have "Very High" and "High" level of knowledge covers $20.31 \%$ and $21.88 \%$ of the total number of respondents, respectively. This signifies that less than half of the respondents were confident with the knowledge they possess about file management. Moreover, the group with the most number falls to the "Poor" level which covers $28.13 \%$ of the responses. $26.56 \%$ of the respondents agreed that they have moderate knowledge about file management. Similar to the first question, there is $3.13 \%$ of the respondents who responded that they have a "Very Poor" understanding of the topic.

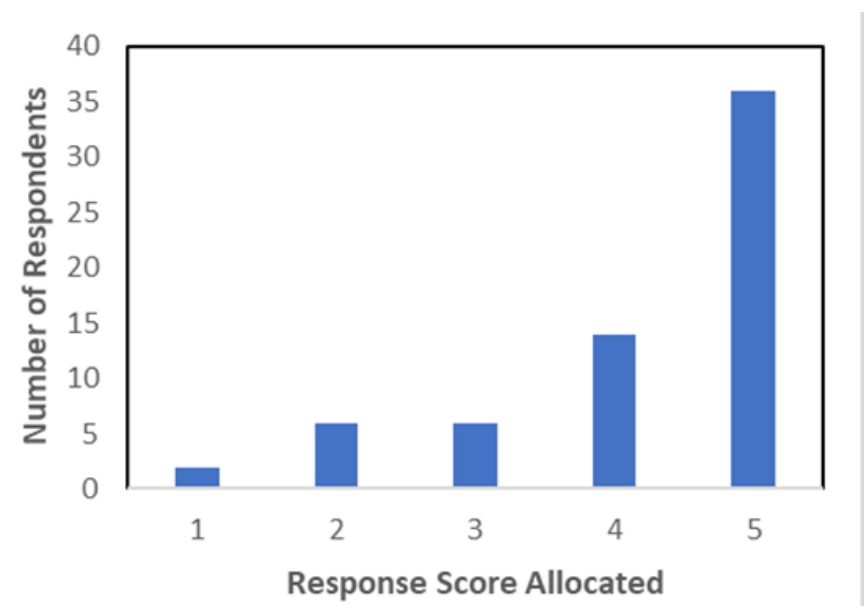

Figure 4. Question Number 3 representation

Legend: Very High $=5$, High $=4$, Moderate $=3$, Poor $=2$, Very Poor $=1$

Table 3. Survey response scores.

\begin{tabular}{|c|c|}
\hline Response Score & Number of Responses \\
\hline 5 & 13 \\
\hline 4 & 14 \\
\hline 3 & 17 \\
\hline 2 & 18 \\
\hline 1 & 2 \\
\hline
\end{tabular}

While pertaining to the barangay secretaries and officials' knowledge on basic computer concepts, most of the responses fall in the "Very High" and "High" range. As shown in Figure 4 and Table 3, in terms of an individual's knowledge in basic computer concepts, $56.25 \%$ and $21.88 \%$ of the respondents positively agreed that they are knowledgeable. On the other hand, only $3.13 \%$ of the staff responded that they are not that knowledgeable of the concepts of software applications and hardware components. Whereas, both responses of "Poor" and "Moderate" have the same number of responses which both covers $9.38 \%$ of the total number of respondents.

These results show that there are barangay officials and secretaries in San Pablo City, Laguna that are knowledgeable on basic concepts of a computer, file management, and following instructions when running a software application. Moreover, it means that there are barangays that can 
International Journal of Managing Public Sector Information and Communication Technologies (IJMPICT)

Vol. 10, No.1/2/3/4, December 2019

perform tasks using ICT equipment which will enable them to provide faster service and will make them more efficient.

\section{RECOMMENDATIONS}

Based on the results of the conducted assessments, all the barangays in San Pablo City are equipped with essential ICT facilities to deliver basic technology-supported services to their constituents. Correspondingly, half of the barangay officials are knowledgeable in handling ICT operations which indicates that room for improvement is necessary, hence, it is recommended to have in-depth training. Because of the arising problems in the local government due to voluminous paper works required by the Department of the Interior and Local Government (DILG), the proponents believed that developing an information system for the services that require a lot of effort and time such as the services under the Katarungang Pambarangay is a must. With that in mind, a use case diagram was designed to illustrate the organization of the recommended system.

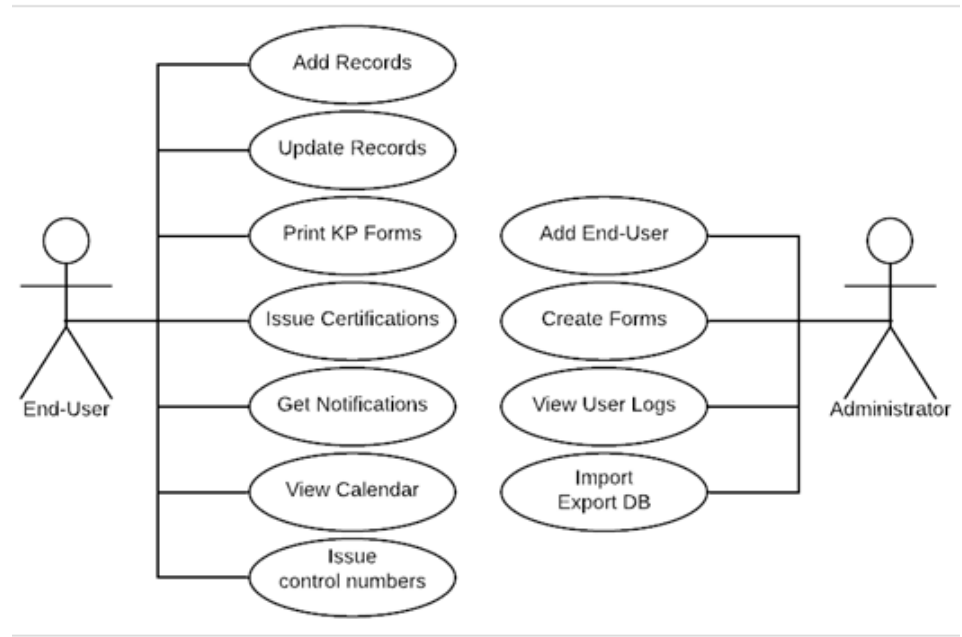

Figure 5. Use Case Diagram of the recommended system

As illustrated above in Figure 5, there will be two actors in the system - an end-user and an administrator. The barangay secretary or any barangay official who will administer the procedures of Katarungang Pambarangay will serve as the end-user of the recommended system while the developer will be the administrator. It is assumed that all identified problems encountered in the processes in Katarungang Pambarangay will be resolved if this system will materialize. The recommended system will allow the end-user to input, update and store records (complaints) for safekeeping and reduce redundant encoding of data, print the Katarungang Pambarangay forms and keeping a soft copy of it, issue documents and certifications, get notifications for the important dates for conducting mediation, conciliation or arbitration to eliminate delay in processing of complaints, view the calendar of activities, and issue and manage the control numbers. On the other hand, on the Administrator side, the system will enable them to manage users by allowing them to add end-users to the system, create forms, provision to import and export database for backup and restore of data, and view user logs (audit trail) to trace the actions of every end-user of the system. 
International Journal of Managing Public Sector Information and Communication Technologies (IJMPICT) Vol. 10, No.1/2/3/4, December 2019

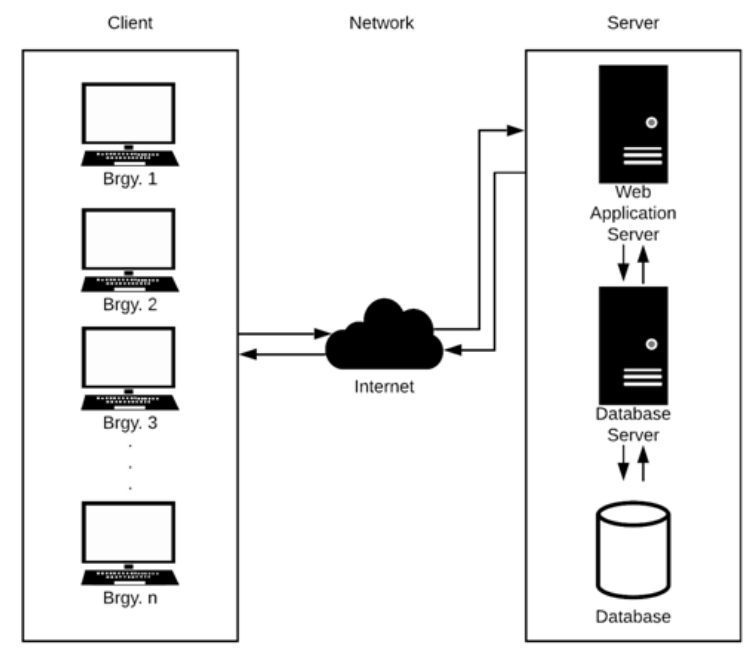

Figure 6. Database architecture of the recommended system

The proponents intend to implement the three-tier architecture as the database architecture on the recommended system. As shown in Figure 6, as the client, each barangay is expected to have at least one terminal (desktop/laptop computer) for them to use the system. To connect to the recommended system application, a terminal is expected to be connected to the internet. Since most of the barangay had internet connectivity, this architecture is much suggested. In the server part of the architecture, a separate server for the web application and the database application is suggested. This will allow the servers to work efficiently by balancing the load to satisfy more client requests. Since there are several barangays expected to utilize the system, having to process more requests is an advantage. Such a feature will make the system more effective and efficient. Moreover, it will enable the users to be satisfied and meet their expectations as well as provide the barangays with a more secure online service.

\section{CONClusions AND Limitations}

Information and Communication Technology (ICT) has played a vital role in enhancing the quality of government processes and/or services particularly in the smallest unit of the Philippine political system which is the barangay. This study determined that there are pressing issues and problems being encountered in implementing the Katarungang Pambarangay. Based on the findings presented in the earlier section, barangays can adopt an information system because there are resources and equipment readily available in their offices. Moreover, the result shows that some of the officials, as well as the staff of the barangays, are equipped with the essential knowledge and skills in using a system. However, it is still recommended to conduct seminars/workshops/training to further enhance their skills and knowledge. The study further shows that integrating an information system in the government process will benefit not just the agency but also the community.

The study only considered the problems and issues collected from the qualitative assessment. Any issues not mentioned in the interview are not considered in the recommended design of the system. In addition, the effectiveness of the proposed system was not considered in this study. Thus, a follow-up study is recommended. 
International Journal of Managing Public Sector Information and Communication Technologies (IJMPICT) Vol. 10, No.1/2/3/4, December 2019

\section{ACKNOWLEDGMENT}

The authors are indebted to the Department of the Interior and Local Government, to the respondents of the study, and the Liga ng Barangay of the City of San Pablo, Laguna. This research was supported by the College of Computer Studies and the Research and Development office of Laguna State Polytechnic University, San Pablo City, Laguna, Philippines.

\section{REFERENCES}

[1] Republic of the Philippines, "Republic Act No. 7160 - An Act Providing for a Local Government Code of 1991," The LawPhil Project, Arellano Law Foundation, Philippine Laws and Jurisprudence Databank. [Online]. Available: https://www.lawphil.net/statutes/repacts/ra1991/ra_7160_1991.html. [Accessed: 21-Sep-2019].

[2] "E-Government Master Plan," iGovPhil Program, 27-May-2015. [Online]. Available: http://i.gov.ph/e-government-master-plan-3/. [Accessed: 21-Sep-2019].

[3] Department of Information and Communications Technology, "eGovernment" DICT, 30-Jul-2014. [Online]. Available: https://dict.gov.ph/egovernment/. [Accessed: 19-Sep-2019].

[4] M. Vigo and M. Manuel, "Katarungang Pambarangay: A Handbook" Pasig City, Philippines: Sentro ng Alternatibong Lingap Panligal (SALIGAN) \& Philippines-Canada Local Government Support Program (LGSP), 2004.

[5] DILG Region 7, "Who we are," Department of the Interior and Local Government - Region VII Official Website, 2011. [Online]. Available: http://dilgregion7.net/aboutus/. [Accessed: 21-Sep2019].

[6] "What you need to know about your LGU" Citizen Action, 2017. [Online]. Available: http://www.citizenaction.net/index.php/research-and-development/197-what-you-need-to-knowabout-your-lgu. [Accessed: 23-Oct-2017].

[7] "Barangays," PhilAtlas, 2019. [Online]. Available: https://www.philatlas.com/barangays.html. [Accessed: 21-Sep-2019].

[8] L. G. S. Bersales, "12 New Barangays Established in the First Quarter of 2018," Philippine Statistics Authority, 24-Apr-2018. [Online]. Available: https://psa.gov.ph/content/12-new-barangaysestablished-first-quarter-2018. [Accessed: 19-Sep-2019].

[9] A. S. M. Al-rawahna1, S. C. Chen and C. W. Hung, " The Barriers of E-Government Success: An Empirical Study from Jordan " International Journal of Managing Public Sector Information and Communication Technologies (IJMPICT), Vol. 9, No. 2, June 2018.

[10] E. C. Lallana, P. Pascual, and E. Soriano, "E-government in the Philippines: Benchmarking against global best practices" Kasarinlan: Philippine Journal of Third World Studies, vol. 17, no. 2, pp. 235$272,2002$.

[11] G. Austral, "A Guide to the Katarungang Pambarangay System". Tagbilaran City, Bohol, Philippines: Philippine Center for Civic Education and Democracy, 2012.

[12] R. A. Sam, A. M. Usop and S. Abubakar-Sam, "Barangay Justice Service System (BJSS) Project as an Alternative Mechanism in Dispute Resolution in Maguindanao, Southern Philippines: A Content Analysis" International Journal of Humanities and Social Science, pp.193-199. 2013. 
International Journal of Managing Public Sector Information and Communication Technologies (IJMPICT)

Vol. 10, No.1/2/3/4, December 2019

\section{AUTHORS}

Joanna E. De Torres received her BS in Information Technology from Laguna State Polytechnic University and MIT degree from the Technological University of the Philippines. She is currently a member of the Faculty of the College of Computer Studies at Laguna State Polytechnic University, Philippines. Her research interests include Performance and Reliability Analysis of Computer Software, e-Government, IT Education, and e-Learning.

Marco Jr. N. Del Rosario received his BS in Information Technology from Laguna State Polytechnic University and Master of Information Technology degree from the Technological University of the Philippines. He is currently a member of the Faculty of the College of Computer Studies at Laguna State Polytechnic University, Philippines. His research interests include Web Development, Performance and Reliability Analysis of Computer Software, e-Government, IT Education, and eLearning.
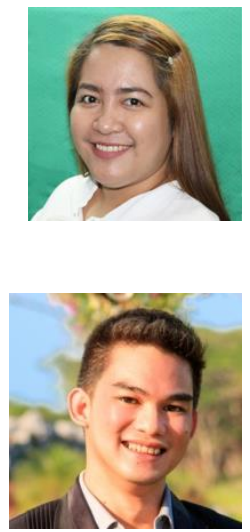